\title{
Mechanisims of asthma and allergic disease - 1071. Chemokines from cord blood mononuclear cells and the development of eczema or wheeze at 2 years of age in infants at high risk for atopy
}

\author{
Phaik Ling Quah ${ }^{1 *}$, Chiung-Hui Huang ${ }^{1}$, Lynette,Pei Shi Shek', Marion Aw', Bee Wah Lee², I-Chun Kuo
}

From 2nd WAO International Scientific Conference (WISC 2012)

Hyderabad, India. 6-9 December 2012

\section{Background}

Innate chemokines secreted from cord blood mononuclear cells (CBMCs) offer novel tools to investigate the influence of immune deviation at birth to the development of eczema or wheeze by 2 years of age.

\section{Methods}

Cord blood samples were collected from 161 subjects from a birth cohort of 253 subjects participating in a doubleblind placebo randomized trial on probiotic supplementation (Lactobacillus rhamnosus GG and Bifidobacteria longum, birth to 6 months). Clinical symptoms for eczema and wheeze were followed up to 2 years of age. The chemokine production in culture supernatants from CBMCs stimulated with $1 \mathrm{ug} / \mathrm{mL}$ of lipopolysaccharides (LPS) for 24 hours was measured using the Milliplex assay. Chemokine levels were analyzed by the Mann-Whitney $U$ Test and the association of chemokines with clinical outcomes was analyzed by the multivariable logistic regression.

\section{Results}

Our results showed that subjects with eczema $(n=36)$ had significantly reduced production of CXCL5 (epithelial neutrophil-activating protein 78 (ENA78)) from CBMCs as compared to healthy control subjects $(\mathrm{n}=94)$ from the LPS stimulated cells $(p=0.001)$. CCL20 (macrophage inflammatory protein- $3 \alpha$ ) levels were significantly lower in the subjects who developed wheeze $(\mathrm{n}=35)$ as compared to healthy controls $(\mathrm{n}=94)$ from the LPS stimulated cells $(p=0.001)$. There was no difference in CXCL5 and

Paediatrics, National University of Singapore, Singapore, Singapore Full list of author information is available at the end of the article
CCL20 production from the cultured unstimulated cells. Diminished CXCL5 production by LPS stimulated CBMCs was found to be independently associated with eczema (adjusted OR, 0.275; 95\% CI, 0.134-0.562, $p=$ 0.001 ) after adjusting for allergen sensitization, paternal eczema and sibling eczema using multivariable logistic regression. Similarly, suppressed production of LPS stimulated CCL20 was an independent risk factor associated to the development of wheeze (adjusted OR, 0.308; 95\% CI, 0.133-0.716, $p=0.06$ ) after adjustment for maternal asthma, sibling eczema, birth height and birth weight.

\section{Conclusions}

We observed the diminished production of CXCL5 and CCL20 by CBMCs from subjects who develop eczema and wheeze respectively within 2 years of age. This association may reflect a deviated innate immune response to microbial or viral infections which might have an impact on the susceptibility of childhood eczema and wheeze.

\section{Author details \\ ${ }^{1}$ Paediatrics, National University of Singapore, Singapore, Singapore. ${ }^{2}$ The Child \& Allergy Clinic, Singapore.}

Published: 23 April 2013

\section{doi:10.1186/1939-4551-6-S1-P68}

Cite this article as: Quah et al: Mechanisims of asthma and allergic disease -1071 . Chemokines from cord blood mononuclear cells and the development of eczema or wheeze at 2 years of age in infants at high risk for atopy. World Allergy Organization Journal 2013 6(Suppl 1):P68.

Fullist of author information is available at the end of the article

@ 2013 Quah et al; licensee BioMed Central Ltd. This is an Open Access article distributed under the terms of the Creative Commons Attribution License (http://creativecommons.org/licenses/by/2.0), which permits unrestricted use, distribution, and reproduction in any medium, provided the original work is properly cited. 